\title{
Ourrateres \\ PENINGKATAN PEMAHAMAN SISWA SMKN 3 SELUMA \\ TENTANG DAMPAK PERNIKAHAN DINI DAN SEX BEBAS SEBAGAI UPAYA PENURUNAN ANGKA KEJADIAN KEHAMILAN DILUAR NIKAH
}

\author{
Bintang Agustina $\mathbf{P}^{*}$, Wulan Angraini, Riska Yanuarti, \\ Program Studi Kesehatan Masyarakat, Fakultas Ilmu Kesehatan, Universitas Muhammadiyah Bengkulu \\ *Corresponding author: bintangagustinap@umb.ac.id
}

\begin{abstract}
ABSTRAK
Sekolah Menengah Kejuruan Negeri (SMKN) 3 merupakan salah satu sekolah di Kabupaten Seluma dengan angka kejadian kehamilan di luar nikah yang cukup tinggi. Informasi yang diperoleh dari pihak sekolah setiap tahunnya ditemukan siswa yang berhenti sekolah dikarenakan hamil. Pemahaman tentang tentang penyebab serta dampak dari perilaku kehamilan di luar nikah sangat diperlukan sebagai upaya pencegahan kehamilan, untuk itu perlu dilakukan penyuluhan tentang Seks Bebas dan Dampak Pernikahan Usia Dini pada siswa SMKN 3 Seluma. Untuk mengatasinya perlu adanya pembinaan kepada remaja tentang bahaya seks bebas, dan Dampak Pernikahan Usia Dini agar mereka mempunyai perbekalan baik pengetahuan dalam menjalankan masa remajanya. Salah satu upaya yang dapat dilakukan adalah melakukan penyuluhan tentang Bahaya Seks dan Dampak Pernikahan Usia Dini sehingga remaja memperoleh ilmu agar pola pikirnya lebih maju dan tidak semakin tertinggal. Remaja desa di SMKN 3 Seluma sangat antusias mengikuti penyuluhan tentang Bahaya Sek Bebas dan Dampak Pernikahan Usia Dini hal ini terlihat dari keaktifan remaja pada acara penyuluhanl melalui beberapa pertanyaan yang mereka ajukan. Di akhir acara penyuluhan dilakukan evaluasi pemahaman remaja tentang bahaya Seks Bebas dan Dampak Pernikahan Usia Dini, semua remaja mampu menjelaskan dampak dari perilaku tersebut. Pemahaman remaja meningkat dari yang belum tahu mejadi tahu dan dapat menghindari hal tersebut agar tidak merusak masa depan mereka. Diharapkan remaja terus berupaya untuk mencari informasi tentang Bahaya Kehamilan Di Luar Nikah serta membuat kegiatan positif diluar kegiatan di sekolah agar tidak melakukan hal-hal negatif.
\end{abstract}

Kata Kunci: Pemahaman, Pernikahan Dini, Seks Bebas

\section{PENDAHULUAN}

Menurut Peraturan Menteri Kesehatan RI nomor 25 tahun 2014, remaja adalah penduduk dalam rentang usia 10-18 tahun. Selain kematangan fisik dan seksual, remaja juga mengalami tahapan menuju kemandirian sosial dan ekonomi, membangun iden tas, akuisisi kemampuan (skill) untuk kehidupan masa dewasa serta kemampuan bernegosiasi (abstract reasoning) (WHO, 2014).
Pada tahun 2016 penduduk remaja berusia 10-24 tahun berjumlah 66,3 juta jiwa dari total penduduk sebesar 258,7 juta sehingga satu di antara empat penduduk adalah remaja. Jumlah generasi

milenial yang cukup besar tersebut merupakan potensi yang memerlukan pengelolaan secara terencana, terstruktur dan sistematis agar dapat bermanfaat menjadi modal pembangunan ke depan. 
Proyeksi Bappenas, jumlah remaja pada tahun 2015 adalah 66 juta jiwa atau sekitar $27 \%$ dari total penduduk, sedangkan jumlah anak sebesar 47 juta jiwa. Artinya pada tahun 2020-2035 komposisi penduduk Indonesia akan diisi oleh tenaga kerja produktif yang sangat berlimpah. Ini adalah bonus demografi yang bisa menguntungkan apabila dikelola dengan baik sejak saat ini.

Mengingat jumlah dan proporsinya yang besar ini pengetahuan, pandangan, sikap dan keputusan remaja sangat berpengaruh, tidak hanya bagi kelompok remaja sendiri namun bagi seluruh penduduk yang tidak hanya berpengaruh pada masa depan, namun juga masa sekarang. Saat ini, terdapat beberapa tantangan yang dihadapi para remaja, yaitu seks pranikah, pernikahan dini, kehamilan, HIV/AIDS dan Napza. Menurut CSIS dan international Youth Foundation tahun dalam laporan The Global Youth Wellbeing Index tahun 2014 mengatakan indeks kesejahteraan remaja secara global menempatkan Indonesia pada posisi ke 19 dari 30 negara.

Remaja pada Usia Sekolah Menengah Atas sangat rawan terhadap paparan seks bebas yang akan berdampak kepada kehamilan di luar nikah. Jika kehamilan ini terjadi pada mereka yang masih duduk di bangku Sekolah menengah atas mau tidak mau pihak keluarga akan memaksa remaja untuk segera menikah. Sementara pernikahan di usia remaja ini tergolong pada pernikahan usia dini.

SMKN 3 seluma merupakan salah satu sekolah kejuruan di Kabupaten Seluma Provinsi Bengkulu. Informasi yang diperoleh dari pihak sekolah setiap tahunnya ditemukan siswa yang menikah saat masih usia Sekolah. Sebagian besar menikah dikarenakan sudah hamil duluan.

Berdasarkan penjelasan diatas dapat ditarik suatu permasalahan bahwa kehamilan di luar nikah merupakan salah satu permasalahan yang terjadi di Sekolah Menengah Kejuruan 3 Kabupaten Seluma. Dengan demikian perlunya sebuah pengabdian masyarakat untuk meningkatkan pengetahuan remaja. Salah satu upaya yang dapat dilakukan adalah melakukan penyuluhan tentang Bahaya Seks Bebas dan Dampak Pernikahan Usia Dini.

\section{METODE KEGIATAN}

Kegiatan ini berlangsung di SMKN 3 Seluma, selama 1 bulan. Metode yang digunakan untuk pemecahan masalah adalah penyuluhan kepada siswa/siswi SMKN 3 seluma. Sebelum penyuluhan diadakan diskusi terkait pemahaman siswa dan setelah penyuluhan juga dilakuan diskusi untuk melihat perubahan pemahaman siswa.

\section{HASIL DAN PEMBAHASAN}

Pengabdian Masyarakat yang dilakukan di SMKN 3 Seluma Kecamatan Air Periukan Kabupaten seluma berjalan sesuai dengan jadwal kegiatan yang telah ditetapkan.

Materi tentang Bahaya seks bebas dan Dampak Pernikahan Usia Dini di sampaikan oleh Mahasiswa dan Dosen Pendamping yaitu Bintang Agustina Pratiwi, MKM. Terjadi peningkatan Pemahaman ramaja setelah dilakukan penyuluhan, adapun Informasi yang diberikan kepada remaja di SMKN 3 Seluma yaitu:

\section{A. Definisi Remaja}

Menurut Permenkes RI nomor 25 Tahun 2014, remaja adalah penduduk dalam rentang usia $10 \quad-18$ tahun. Sedangkan menurut BKKBN rentang usia remaja adalah $10-24$ tahun dan belu menikah. Masa remaja merupakan periode pertumbuhan dan perkembangan yang pesat baik fisik, psikologis maupun intelektual. Sifat khas remaja mempunyai rasa keingintahuan yang besar.

Implikasi perkembangan psikomotor dan fisik masa anak dalam pendidikan misalnya dalam membimbing remaja dalam tugas perkembangan masa remaja, yaitu Mencapai hubungan yang lebih matang 
dengan teman sebaya. Mencapai peran sosial sebagai pria atau wanita. Menerima keadaan fisik dan menggunakannya secara efektif. Mencapai kemandirian emosional dari orang tua dan orang dewasa lainnya. Mencapai jaminan kemandirian ekonomi. Memilih dan mempersiapkan karier. Mempersiapkan pernikahan dan hidup berkeluarga. Mengembangkan keterampilan intelektual dan konsepkonsep yang diperlukan bagi warga negara. Mencapai perilaku yang bertanggung jawab secara sosial. Memperoleh seperangkat nilai sistem etika sebagai petunjuk/pembimbing dalam berperilaku. (Sunarto,2009)

Masa remaja ditandai dengan adanya berbagai perubahan, baik secara fisik maupun psikis, yang mungkin saja dapat menimbulkan problema atau masalah tertentu bagi si remaja. pabila tidak disertai dengan upaya pemahaman diri dan pengarahan diri secara tepat, bahkan dapat menjurus pada berbagai tindakan kenakalan remaja dan kriminal.

B. Masalah yang terjadi Pada Masa Remaja

\section{a. Perilaku Seks Bebas}

Menurut Sarwono (2004) seks bebas adalah segala tingkah laku yang didorong oleh hasrat seksual baik dengan lawan jenis maupun sesama jenis, mulai dari tingkah laku yang dilakukannya seperti sentuhan, berciuman (kissing) berciuman belum sampai menempelkan alat kelamin yang biasanya dilakukan dengan memegang payudara atau melalui oral seks pada alat kelamin tetapi belum bersenggama (necking, dan bercumbuan sampai menempelkan alat kelamin yaitu dengan saling menggesek-gesekan alat kelamin dengan pasangan namun belum bersenggama (petting, dan yang sudah bersenggama (intercourse), yang dilakukan diluar hubungan pernikahan. Faktor yang mempengaruhi remaja :

1) Minspersepsi terhadap makna pacaran yang menanggap hubungan seks adalah sebuah pencitraan rasa kasih sayang

2)Factor lingkungan dikalangan remaja itu sendiri

3) Kematangan biologis seseorang yang tidak disertai kemampuan mengendalikan diri

4) Kurangnya perhatian lebih dari orangtua dan lingkungan masyarakat tentang pemahaman seks yang lebih matang

5) Terlupakannya intisari adat budaya bangsa akibatnya pengaruh globalosasi

6) Dan kurangnya iman dan pemahaman agama yang dimiliki oleh remaja dimasa ini.

a) Dampak yang timbul dari Perilaku Seks Bebas:

1) Beberapa penyakit yang akan menyerang para remaja seperti, herpes, HIV aids, raja singa (sipilis), dan yang lainnya

2) Hamil diluar nikah yang akan menghambat segalanya dan menimbulkan permasalahan yang akan mengganggu kehidupan remaja kita yang sangat indah ini

3) Setelah hamil berfikir akan menggugurkan janin atau kandungan , dan melakukan segala macam cara yang instan agar semuanya dapt kembali seperti semula tanpa ada masalah yang menghambat lagi

4) Atau akan jujur pada orangtua dan pasangan lalu memutuskan untuk menikah muda, sedangkan anda belum siap untuk menghadapi permasalahan yang datang setelah menikah nanti

5) Nama baik keluarga akan tercoreng karna citra buruk yang timbul akibat permasalahn ini, dan yang pasti adalah dosa yang berat akan datang. 
b)Cara mencegah hubungan Perilaku seks bebas :

1) Tingkatkan keimanan dan selalu dekatkan diri kepada Tuhan Yang Maha Esa.

2) Jauhilah narkotika dan pergaulan tanpa batas.

3) Tumbuhkan norma dan nilai-nilai sosial.

4) Hindari hal-hal negatif.

5) Isi hari-hari dengan beraktivitas dan berolahraga.

6) Hindari pergaulan negatif.

7) Selektif terhadap teman-teman sebaya.

8) Hati-hati mengikuti perkembangan teknologi.

9) Hidup sehat tanpa terpengaruh narkotika.

10) Jangan hancurkan masa depan diri sendiri.

11) Capai cita-cita tanpa seks bebas.

12) Pikirkan segala tindakan dengan efektif dan komprehensif sesuai dengan akibat yang akan kita terima.

13) Hindari seks bebas sejak dini dengan tidak bergaul tanpa batasan norma dan etika.

\section{b. Pernikahan Usia Dini}

Pernikahan dini (early mariage) merupakan suatu pernikahan yang dilakukan oleh seseorang yang memiliki umur yang relatif muda. Umur yang relatif muda yang dimaksud tersebut adalah usia pubertas yaitu usia antara 10-19 tahun. Permasalahan kesehatan reproduksi dimulai dengan adanya pernikahan dini yang hasilnya yaitu pada perempuan usia 10-54 tahun terdapat 2,6 persen menikah pada usia kurang dari 15 tahun kemudian 23,9 persen menikah pada usia 15-19 tahun.

Hasil Riskesdas Provinsi Bengkulu tahun 2010 menunjukan, usia perkawinan pertama perempuan kelompok umur 15-19 tahun di Bengkulu mencapai 45,9 persen angka ini lebih tinggi dari angka rata rata nasional yang sebesar 41,9 persen, sedangkan usia perkawinan pertama kelompok umur 10 - 14 tahun di Provinsi Bengkulu termasuk tertinggi nomor 6 (enam) se Indonesia yaitu 6,5 Persen (Kemenkes, 2010)

Berdasarkan Profil

Kependudukan dan

Pembangunan Provinsi

Bengkulu tahun 2015 usia menikah pertama menunjukkan tren yang naik dari tahun 1991 sebesar 17 tahun, 1997 sebesar 18 tahun dan tahun 2012 sebesar 14,43 tahun. Rata-rata umur menikah pertama di Provinsi Bengkulu adalah 19,79 tahun masih terdapat 7 kabupaten yang berada di bawah rata-rata yaitu Seluma (18,96), Muko-muko(19,06), Bengkulu Tengah dan Kepahiang $(19,13)$, Kaur $(19,35)$, Lebong $(19,43)$ dan Rejang Lebong $(19,56)$.

\section{a) Faktor Penyebab Pernikahan} Usia Dini

Penelitian yang dilakukan oleh Khaparistia (2015) membuktikan bahwa terdapat beberapa factor yang menjadi penyebab tingginya angka menikah di usia muda. Faktor utamanya adalah masalah ekonomi yang kurang, faktor pendukung lainnya adalah pengaruh teman sebaya, keinginan dari informan, keluarga, dan hamil di luar nikah.

Penelitian Hotchkiss (2016) yang dilakukan di kota Roma (Serbia) ditemukkan Praktik perkawinan anak (15-17 tahun) paling umum terjadi pada anak perempuan yang tinggal di 
rumah tangga miskin, berpendidikan kurang, dan tinggal di pedesaan.

Evenhuis

menyampaikan perempuan di daerah pedesaan dua kali lebih mungkin untuk menikah pada usia 18 tahun bila dibandingkan dengan perempuan di kota. Selain itu perempuan yang tidak sekolah tiga kali lebih mungkin untuk menikah Bila dibandingkan dengan perempuan yang menempuh pendidikan sampai sekolah menengah. Anak yang menikah usia dini lebih cenderung memilih pasangan sendiri; Artinya, anak perempuan memilih untuk menikah karena alasan kompleks termasuk stigma seks pra nikah dan kehamilan.

Perkawinan usia kurang dai 18 tahun paling sering terjadi pada masyarakat patriarkal di mana orang tua memiliki peran penting dalam memilih pasangan untuk anak-anak mereka. Anak perempuan sering menikah tak lama setelah pubertas untuk memaksimalkan potensi melahirkan anak mereka. Banyak budaya memberi penekanan pada perempuanan, yang sangat terkait dengan kehormatan keluarga. Orangtua dapat menikahkan seorang anak perempuan pada usia dini untuk memastikan bahwa dia menikah sebagai perawan dan untuk mencegah kelahiran di luar nikah (Council on Foreign Relation, 2013).

b) Dampak Pernikahan Usia Dini Praktik perkawinan usia anak seringkali menimbulkan dampak buruk terhadap status kesehatan, pendidikan, ekonomi, keamanan anak perempuan dan anak-anak mereka, serta menimbulkan dampak yang merugikan bagi masyarakat. Berikut dampak pernikahan usia dini menurut Badan Pusat Statistik (2015):

1) Bagi Anak Perempuan

a. Kehamilan Berisiko

Perkawinan usia anak menyebabkan kehamilan dan persalinan dini, yang berhubungan dengan angka kematian yang tinggi dan keadaan tidak normal bagi ibu karena tubuh anak perempuan belum sepenuhnya matang untuk melahirkan (Centre for Reproductive Rights, 2013)). Anak perempuan usia 10-14 tahun memiliki risiko lima kali lebih besar untuk meninggal dalam kasus kehamilan dan persalinan daripada perempuan usia 20-24 tahun, dan secara global kematian yang disebabkan oleh kehamilan merupakan penyebab utama kematian anak perempuan usia 1519 tahun (WHO. 2014). Anak Perempuan menghadapi risiko tingkat komplikasi yang terkait dengan persalinan yang jauh lebih tinggi, seperti fistula obstetri, infeksi, perdarahan hebat, anemia dan eklampsia. Terdapat kajian yang menunjukkan bahwa perkawinan usia anak di Indonesia berhubungan dengan buruknya kesehatan reproduksi dan kurangnya kesadaran anak perempuan terhadap risiko persalinan dini.

b. Pendidikan Terhenti

Anak perempuan yang telah menikah cenderung memiliki tingkat pendidikan yang lebih rendah. Hal ini disebabkan perkawinan dan pendidikan dianggap bertentangan ketika anak perempuan yang menikah menghadapi keterbatasan mobilitas, kehamilan dan tanggung jawab terhadap perawatan anak. Menurut salah 
satu laporan, 85 persen anak perempuan di Indonesia mengakhiri pendidikan mereka setelah mereka menikah, namun keputusan untuk menikah dan mengakhiri pendidikan juga dapat diakibatkan kurangnya kesempatan kerja (Evenhuis, 2014). Terdapat sekolah di Indonesia yang menolak anak perempuan yang telah menikah untuk bersekolah (Simanjuntak, 2016). Anak perempuan dengan tingkat pendidikan yang lebih rendah lebih tidak siap untuk memasuki masa dewasa dan memberikan kontribusi, baik terhadap keluarga mereka maupun masyarakat (Evenhuis, 2014). Mereka memiliki lebih sedikit suara dalam pengambilan keputusan dalam rumah tangga dan kurang mampu mengadvokasi diri mereka sendiri atau anakanak mereka. Mereka juga kurang mampu untuk memperoleh penghasilan dan memberikan kontribusi finansial bagi keluarga. Hal-hal tersebut dapat meningkatkan angka kemiskinan (ICRW, 2005).

c. Beban Ganda

Perkawinan pada usia muda membebani anak perempuan dengan tanggung jawab menjadi seorang istri, pasangan seks, dan ibu, peran-peran yang seharusnya dilakukan orang dewasa, yang belum siap untuk dilakukan oleh anak perempuan. Perkawinan ini juga menimbulkan beban psikologis dan emosional yang hebat bagi mereka. Selain itu juga terdapat kesenjangan usia, dimana anak perempuan jauh lebih muda dari pasangan mereka. Berbagai kajian menunjukkan bahwa anak perempuan yang menikah pada usia dini memiliki risiko tinggi untuk mengalami kecemasan, depresi, atau memiliki pikiran untuk bunuh diri, sebagian dapat disebabkan mereka tidak memiliki status, kekuasaan, dukungan, dan kontrol atas kehidupan mereka sendiri (Raj, 2013). Selain itu mereka juga kurang mampu untuk menegosiasikan hubungan seks aman, sehingga meningkatkan kerentanan mereka terhadap infeksi menular seksual seperti HIV.

d. Kekerasan Rumah Tangga

Kajian lain juga menunjukkan bahwa pengantin anak memiliki peluang lebih besar untuk mengalami kekerasan fisik, seksual, psikologis, dan emosional, serta isolasi sosial, yang merupakan akibat dari kurangnya status dan kekuasaan mereka di dalam rumah tangga mereka. Pengantin muda lebih sering mengalami kekerasan. Di Indonesia, kekerasan dalam rumah tangga dianggap wajar oleh sebagian besar orang muda: 41 persen anak perempuan usia 15-19 tahun percaya bahwa suami dapat dibenarkan dalam memukul istrinya karena berbagai alasan termasuk ketika istri memberikan argumen yang bertentangan (UNICEF, 2012).

2) Bagi Anak-anak yang dilahirkan Perkawinan usia anak memiliki dampak antargenerasi. Bayi yang dilahirkan oleh anak perempuan yang menikah pada usia anak memiliki risiko kematian lebih tinggi, dan kemungkinannya dua kali lebih besar untuk meninggal sebelum usia 1 tahun dibandingkan dengan anak-anak yang dilahirkan oleh seorang ibu yang telah berusia dua puluh tahunan. Bayi yang dilahirkan oleh pengantin anak juga memiliki kemungkinan yang lebih tinggi untuk lahir prematur, dengan berat badan lahir rendah, dan kekurangan gizi. Hal ini berhubungan langsung perempuan menikah yang pada saat kehamilan dan persalinan masih berusia sangat muda, ketika mereka 
sendiri memiliki tingkat kekurangan gizi yang lebih tinggi dan tubuh mereka belum tumbuh sempurna (Mason, 2014). Ketika anak perempuan masih dalam proses pertumbuhan, kebutuhan gizi pada tubuhnya akan bersaing dengan kebutuhan gizi pada janinnya (Fall, 2015).

Menurut kajian di antara 5 negara berpenghasilan rendah dan menengah, terdapat 20-30 persen peningkatan risiko kelahiran prematur dan berat bayi lahir rendah di antara anak-anak ketika ibu mereka berusia kurang dari 20 tahun. Anak-anak yang dilahirkan oleh ibu-ibu yang berusia kurang dari 19 tahun memiliki 30-40 persen peningkatan risiko hambatan pertumbuhan (stunting) selama 2 tahun dan kegagalan untuk menyelesaikan sekolah menengah .(Fall, 2015).

3) Bagi Masyarakat

Perkawinan usia anak tidak hanya mendasari, tetapi juga mendorong ketidaksetaraan gender dalam masyarakat. Perkawinan usia anak dapat menyebabkan siklus kemiskinan yang berkelanjutan, peningkatan buta huruf, kesehatan yang buruk kepada generasi yang akan datang, dan merampas produktivitas masyarakat yang lebih luas baik dalam jangka pendek maupun jangka panjang. Meskipun kajian-kajian untuk mengetahui dampak perkawinan usia anak terhadap masyarakat sangat sedikit, tetapi perhatian terhadap topik tersebut terus berkembang.

Kajian yang dilakukan oleh The World Bank memperkirakan bahwa perkawinan usia anak di beberapa negara di sub-Sahara Afrika memberikan kontribusi terhadap seperlima pelajar perempuan yang putus sekolah menengah. Kajian tersebut menghitung bahwa setiap penundaan satu perkawinan dapat berpotensi untuk meningkatkan kemungkinan melek huruf dan menyelesaikan sekolah menengah beberapa persen. Kajian tersebut menyimpulkan bahwa "investasi pada anak perempuan sampai mereka menyelesaikan tingkat pendidikan selanjutnya akan menghasilkan pendapatan seumur hidup dari kelompok anak perempuan saat ini yang setara dengan 68 persen produk domestik bruto tahunan."(Chaaban. 2011) Kajian lain yang dilakukan oleh UNICEF di Nepal menyatakan bahwa hilangnya kesempatan bersekolah sebagai akibat dari perkawinan usia anak adalah sebesar 3,87 persen dari Produk Domestik Bruto (PDB)(Rabi.2014). Kajiankajian dengan temuan yang sama telah dilakukan di Bangladesh dan di negara-negara lain, dan lebih banyak riset sedang dilakukan untuk lebih memahami kerugian ekonomi dari perkawinan usia anak.

Kajian

pembiayaan eksploratif yang dilakukan oleh UNICEF mengkaji dampak perkawinan usia anak dan remaja terhadap perekonomian Indonesia dengan memperkirakan dampak penundaan perkawinan anak perempuan terhadap pasar tenaga kerja. Kajian tersebut menjelaskan kelompok anak perempuan menikah usia 15-19 tahun selama 36 tahun ke depan. Dengan menggunakan perkiraan konservatif, kajian tersebut menunjukkan bahwa penundaan usia perkawinan anak perempuan sampai 20 tahun dapat meningkatkan 1,70 persen PDB pada tahun 2014. Hasil ini menunjukkan bahwa investasi pada anak perempuan memiliki dampak besar terhadap 
perekonomian Indonesia selama masa produktif mereka dan penundaan perkawinan mendukung potensi ini. Hasilnya menunjukkan bahwa kurangnya investasi dalam penundaan perkawinan bagi remaja perempuan dan hilangnya kesempatan pendidikan dan hilangnya penghasilan seumur hidup yang diakibatkannya akan terus menimbulkan dampak negatif yang kuat terhadap perekonomian Indonesia (Rabi, 2015).

5. Evaluasi Hasil Penyuluhan

Evaluasi dari hasil penyuluhan dilakukan dengan memberikan beberapa pertanyaan kepada peserta penyuluhan. Bagi remaja yang mampu menjawab pertanyaan dari pemateri maka akan diberikan hadiah

Pada saat pemateri memberikan pertanyaan semua remaja sangat antusias untuk menjawab pertanyaan yang diajukan. Dari jawaban yang mahasiswa berikan terlihat bahwa pemahaman mereka tentang bahaya seks bebas dan dampak pernikahan usia dini. Diharapkan remaja mampu mengontrol perilaku mereka dengan pengetahuan yang dimiliki. Dari awal hingga akhir acara semua berjalan dengan baik. Para remaja sangat tertarik dengan tema yang dibahas, banyak remaja yang bertanya tentang bahasa seks bebas dan bagaimana cara mengingatkan teman yang sudah mempunyai pacar di usia sekolah

6. Penutup

Di akhir acara dilakukan penandatanganan Berita Acara Penyuluhan Oleh Kepala Sekolah

\section{PENUTUP}

Terjadi peningkatan pengetahuan remaja tentang Bahaya seks bebasdan Dampak Pernikahan Usia Dini. Selain itu menunjukkan perubahan sikap sikap penolakan (tidak setuju) terhadap perilaku seks bebas, pernikahan usia dini.

\section{DAFTAR PUSTAKA}

BPS. 2016. Perkawinan Usia Anak Di Indonesia Tahun 2013 dan 2015. Jakarta; BPS

BPS. 2015. Kemajuan yang Tertunda: Analisis Data Perkawinan Usia Anak di Indonesia.Jakarta;BPS

BPS. 2013. Survey Sosial Ekonomi Nasional: Statistik Kesejahteraan Rakyat. Jakarta;BPS

BKKBN Prov Bengkulu. 2017. Tingginya Angka menikah dini BKKBN Gelar Workshop Genre yang diakses dari http://bengkulu.bkkbn.go.id/Lists/ Berita/DispForm.aspx?ID=1736\& ContentTypeId=0x0100A28EFC BF520B364387716414DEECEB $1 \mathrm{E}$

Centre for Reproductive Rights. (2013). Accountability for Child Marriage: Key U.N Recommendations to Governments in South Asia on Reproductive Health and Sexual Violence (Fact Sheet). New York: CFRR, p. 4; and Kim, M. et al., (2013). When Do Laws Matter? National Minimum-Age-of-Marriage

Laws, Child Rights, and Adolescent Fertility, 1989-2007. Law \& Society Review, 47, (3), pp. 589, 591.

Chaaban, J. and W. Cunningham. (2011). Measuring the Economic Gains of Investing in Girls: The girl effect dividend. Policy Research Working Paper. The World Bank, Washington, D.C.: The World Bank.

Evenhuis, Mark and Jennifer Burn. (2014). Just Married, Just a Child: Child marriage in the Indo-Pacific region. Melbourne: Plan International Australia 
Fall, C.H.D., et al. (2015). Association between maternal age at childbirth and child and adult outcomes in the offspring: a prospective study in five lowincome and middle- income countries (COHORTS collaboration). Lancet Glob Health 2015; 3: e366-77, p 366. Hotchkiss, David R.. Godha, Deepali. Gage, Anastasia J. Cappa, Claudia. 2016. Risk factors associated with the practice of child marriage among Roma girls in Serbia. BMC International Health and Human Rights (2016) 16:6 DOI 10.1186/s12914-016-0081-

3Ending Child Marriage: Progress and prospects, p. 3; and World Bank. (2012), World Development Report on Gender Equality and Development. p. 154, fig. 4.3.

ICRW. (2005). Development Initiative on Supporting Health Adolescents (DISHA) Project: Analysis of quantitative baseline survey data conducted in 2004. Washington, D.C: ICRW and Mathur, Greene and Malhotra. (2003). Too Young to Wed: The lives, rights and health of young married girls. Washington, D.C.: ICRW.

Kemenkes. 2010. Riset Kesehatan Dasar 2010.Jakarta

Khaparistia, EKa. Edward. 2015. Faktor-Faktor Penyebab

Terjadinya Pernikahan Usia Muda ( Studi Kasus di Kelurahan Sawit Seberang Kecamatan Sawit Seberang Kabupaten Langkat). Jurnal Ilmu Kesejahteraan Sosial Vol. 14, No. 1, Juni 2015

Mason, J. B., et al. (2014). The first 500 days of life: policies to support maternal nutrition
Raj, A. When the mother is a child, p. 931; Gage, A.J. (2013). Association of child marriage with suicidal thoughts and attempts among adolescent girls in Ethiopia. Journal of Adolescent Health, 52, (5), p. 654; and Evenhuis and Burn, Just Married, Just a Child, p. 20.

Simanjuntak, A. D. (2016). Studi Kasus Kualitatif Pasangan Suami Istri Yang Menikah Tanpa Pacaran di Kota Medan. Jurnal Ilmu Komunikasi FLOW, 2(14).

Undang Undang Perlindungan Anak No. 23 tahun 2002

UNICEF. 2001...Early Marriage Child Spouses. Innocenti Degest, No. 1 Maret 2001. Diakses dari http://www.unicefirc.org/publication/pdf/digest7e. pdf

UNICEF. (2012). Progress for Children: A report card on adolescents: Number 10. New York: New York: UNICEF. p. 47.

WHO. (2014). World Health Statistics 2014. Geneva, Switzerland: World Health Organization;

Sarwono, S. W. (2004). Psikologi remaja. Edisi revisi 8. Jakarta : Raja Grafindo Pustaka

Sunarto, Agung.2009. Kebutuhan Remaja, Masalah, dan Konsekuensinya. Jakarta: Rineka

Rabi, A. (2014). Cost of Inaction: Child and adolescent marriage in Nepal. UNICEF.

(2015). Technical Note. Cost of Inaction: Child and adolescent marriage in Indonesia. UNICEF Indonesia (unpublished). 